\title{
Analysis of obstacles to green building projects: the experience of Russia and Europe
}

\author{
Mikhail Leontev ${ }^{1, *}$ \\ ${ }^{1}$ Moscow State University of Civil Engineering, 129337, Moscow, Russia
}

\begin{abstract}
This paper examines the issues of ecological (green) construction in the framework of the concept of sustainable development - an inevitable global trend. The scale of ecological (green) construction is still limited throughout the world, including in Russia. Green building appeared in Russia much later than in Europe and the United States, where considerable experience has been accumulated in the implementation of such projects. It is necessary to better understand the obstacles to the implementation of green projects in order to find ways and means to overcome them. In this study, 19 obstacles to the implementation of green building projects in Russia were identified. The most important obstacles turned out to be: lack of necessary knowledge and information about green building among construction subjects, higher cost of green building compared to conventional, lack of interest and market demand for green building. The results of this study provide information that is valuable in the design and implementation of green building projects in the future.
\end{abstract}

\section{Introduction}

Sustainable development is an inevitable global trend. However, the scale of green building is still limited worldwide. Previous studies have attributed this to the influence of various factors, such as government policies in this area, green building assessment and certification processes, integrative project management, perception of construction costs by its participants, as well as customers and potential consumers, and so on [1].

In addition to the above, the rationale for green building projects and the associated social issues, profitability and tangible benefits of green buildings are also controversial. Thus, in order to facilitate the process of sustainable development of territories, there is an urgent need to investigate the factors affecting the efficiency of work and material benefits associated with green buildings and structures in architecture and construction. Green building projects have something in common - all homogeneous and heterogeneous green real estate objects are united by one ultimate goal, and their construction is carried out in a complex manner, as a rule, on a certain territory with the allocation of modules [2].

The United Nations Environment Program (UNEP) in its study "Towards a Green Economy: Pathways to Sustainable Development and Poverty Eradication" defines an ecological ("green") economy as an economy that leads to "improved human well-being and social equality while significantly reducing environmental risks and environmental deficits",

\footnotetext{
*Corresponding author: miillen@rambler.ru
} 
which aims to achieve "green" growth. A number of social-and-economic benefits obtained from the green economy are also listed: preservation and assessment of natural capital, reduction of poverty and unemployment, energy independence, efficient use of resources and electricity [3].

But, despite the receipt of a number of benefits for society as a whole, there remain a number of factors that restrain the transition to an "ecological" economy and the achievement of its growth: imperfection of market mechanisms in the field of ecology, uncertainty of investors in the "green" economy, the problem of methods for measuring green economy growth; the banking sector's preference for existing (conventional) approaches, technologies and companies in construction and architecture [4]. Based on these factors and the higher costs of environmental projects, the urgent problem is to attract investments in the green economy and ensure green growth.

A number of developed countries have made some progress in the transition from a traditional to a "green" economy and its financing. The UK government has great ambitions for a low carbon, energy efficient and sustainable economy. Implementation of the green economy transition in the United Kingdom began with the adoption of the Climate Change Act 2008 , which aims to reduce of carbon dioxide emissions by $80 \%$ by 2050 , compared to baseline 1990. Germany became one of the first countries in the field of "green" policy; in 1971, the first federal environmental program was proposed. At the same time, investments in environmental protection began to be encouraged through subsidizing interest rates [5].

Based on the above, construction, as an important branch of the economy, is subject to current requirements for the "environmental friendliness" of construction products and real estate. These requirements are reflected in the resolution of the United Nations Conference on Human Settlements (Habitat), which proclaims the principles of human settlements development that minimize the negative anthropogenic impact on the environment and provide protection, replenishment of natural environment objects and their preservation for future generations. Summarizing the requirements contained in the resolution [6], the following areas of sustainable development of settlements related to the characteristics of construction products and real estate objects can be distinguished: energy and resource conservation, safety of building materials, predominant use of local building materials, functionality of real estate objects, reduction in construction cost and reducing the cost of selling construction products.

Recently, a certain experience has been accumulated in Russia, and several specific national directions of energy conservation policy have been formed both at the state and regional levels. The transition to ecological (green) building indicates innovative changes for enterprises in the construction industry in Russia.

The practical implementation of green building projects in Russia is currently complicated by their specificity and scale, as well as the lack of motivation of the developers and consumers in such projects. Green building projects have a number of specific features. Development on the territory of the region within the framework of green projects is characterized by its scale (ecological settlements, parks, etc.), as well as by a wide variety of facilities under construction, including industrial, housing and civil, social, transport and other buildings and infrastructure facilities. Also, green building projects are characterized by an uneven distribution of work within the construction area, the use of various materials and structures, complex equipment, and the involvement of a large number of sub-contracting organizations [1]. In addition, large green building projects are immediately built up on large plots for a long time. Commissioning of facilities is carried out gradually, as they are ready, the implementation period of the entire project can be from 10 to 20 years.

The need for energy efficient and environmentally friendly construction is enshrined in a number of the most important strategic documents of the Russian Federation, including the Strategy for the Development of the Building Materials Industry for the Period until 2020 
and the Further Outlook until 2030. The national project "Housing and Urban Environment" includes four federal projects: "Mortgage", "Housing", "Formation of a Comfortable Urban Environment" and "Ensuring a Sustainable Reduction of Unsuitable Housing Stock», the implementation period of the national project: from October 2018 to 2024 year. Also, a draft Strategy for the innovative development of the construction industry for the period up to 2030 was developed.

Despite many years of criticism, a linear approach to green building projects still prevails. With this approach, customers (consumers) are the initiators of any innovation or change [7]. Although there are certain levels of awareness and interests of the parties in the green building sector, various studies have shown that the current social awareness, perception of green building by stakeholders and the demand for it are insufficient for the sustainable development of this area [8]. In general, sustainable development is perceived as more costly, requiring workers with a higher level of competence and higher technological know-how. Such perceptions of the risks of green building discourage companies and firms.

Governments around the world have proposed various types of measures to promote sustainable development and green policies in architecture, construction, and real estate. The success of these measures depends on several key factors.

First, the complexity of laws and regulations can make it difficult to make sustainable development decisions. Previous studies have shown that developers have found it difficult to estimate the initial cost of a green building project due to the complexity and ambiguity of regulations. Second, the development of a comprehensive and integrated package of interventions is essential to help ensure the full cycle of sustainable development. For example, you can pay too much attention to energy and resource conservation, while not paying constant attention to the systematic nature of green building [9]. Third, financial instruments to encourage green building, such as tax breaks, deductions, and facility operating discounts, can also be very important. Due to the high initial cost and long payback period of sustainable development facilities [10], tax incentives do not sufficiently motivate developers to invest in sustainable development projects. Fourth, non-financial stimulation of green projects in construction, for example, technical support, legal support for paperwork, consulting and assistance in creating a business plan, at the investment stage, etc. [11].

In recent decades, various assessment and certification systems for green building have been developed around the world. Historically, the first voluntary standard BREEAM was created in 1990, by the British company BRE Global as a method for assessing the environmental performance of buildings, now used all over the world. In 1998, the Leadership in Energy and Environmental Design (LEED) standard was developed by the American Green Building Council. Further, the situation developed according to two scenarios: either one of the two standards was taken as a basis, but the boundary values of the indicators were determined in accordance with the national legislation and strategic documents of each country, or their own national standard was developed.

All systems have a number of common features, first of all, these are target groups (for which standards have been created): investors, developers, designers, builders, management companies, the public and the very principles of building assessment systems. LEED certification pays more attention to the energy efficiency of the facility, while BREEAM focuses on the sustainability and quality of building materials.

Germany, one of the first successful countries in energy efficiency in construction, has a Sustainable Building Certificate from the German Sustainability Building Council (DGNB). It is a voluntary certification system based on six categories: ecology, economy, society and culture, functionality, technical quality, processes and territory. Built on the basis of local codes and regulations, the system assesses the overall building performance and life cycle, not individual metrics [12]. France has a Haute Qualite Environment (HQE) certification 
system. Four areas are taken into account by this certification system: energy, environment, health and comfort [13].

Today, there are 32 national standards systems in 24 countries around the world. Moreover, in some countries there are several standards. Despite regional preferences in the application of national certification systems, BREEAM and LEED systems are dominant today [14]. The adherence to these systems is understandable from the point of view of international investors who seek to evaluate their real estate portfolios according to uniform and understandable criteria in any country. On the other hand, the presence of competition in the certification market is seen as a positive factor in terms of progress and adaptation of systems.

Although these two systems of standards have different objectives and areas of assessment, they are similar in terms of the working framework of the assessment. However, there is uncertainty as to whether any regional assessment scheme will accurately reflect the extent to which a construction project meets sustainable development criteria.

On the other hand, some of the green building certification systems are perceived as being too strict or time-consuming, which is a barrier to joining. For example, LEED is one of the most popular green building rating systems in the world. However, it was commented on as being too complicated, complex and time-consuming [15].

While in Europe and the United States, standards for sustainable construction have existed since the early $1990 \mathrm{~s}$, energy conservation programs are being successfully implemented, and grants for research in this area are being issued, in Russia these issues have long remained insufficiently studied. Green building in Russia appeared much later than in Europe and the United States, but the state is currently actively stimulating the construction industry to develop in this direction, and in the future this trend will only grow.

The benefits of green building projects are largely in line with human health and sustainable development requirements, but there are some concerns about such projects. A better understanding of the obstacles to green building projects is needed to help find ways and means to overcome them.

Project sustainability is driven by stakeholder engineering values and approaches to environmental performance management throughout the project lifecycle. Previous studies have shown that early inclusion of sustainability issues in project management can reduce the cost of a green project. Cost has been the main obstacle to the introduction of green building [9].

In construction, cost and timing are closely related, as they are both important in assessing the effectiveness and success of a project. The increase in time, the shift in implementation time due to the implementation of environmental requirements was an inevitable obstacle to decision-making by contractors, clients, consultants and subcontractors. In addition, the approval process of a green project usually takes longer. This circumstance requires additional time for green building projects [16].

The successful implementation of a green project requires effective cooperation and productive contacts among various stakeholders within the framework of a specific project. Consequently, lack of interest in the project, lack of communication between members of the project team can negatively affect the implementation of a green project.

Knowledge and information about green building, certification systems, construction methods, products are the key to successfully promoting green building. There is still a lack of knowledge and information about green products, construction methods, certification systems and cost data in the construction industry.

Vocational education and training in sustainable development has also been criticized for its inadequacy [17]. On the other hand, cost data, including capital and operating costs, is key to motivating developers to invest in sustainability. Therefore, it is proposed that various cost estimation methods help to fully understand the economic benefits of green buildings [18]. 
It is possible to highlight the principles, approaches and available technologies that can be applied in green building in order to ensure the environmental safety of construction activities. The vigorous activity of supporters of green building abroad over the past decades has already borne noticeable results. A big step forward was the creation of the World Green Building Council (WorldGBC), which unites over 70 member countries.

Today, many large corporations create special units for green building in their structures. In the USA, in the EU countries, it has become more profitable to build housing, offices according to eco-standards, they are easier to sell, rent, even if you have to pay a little more. These expenses are paid off by increasing labor productivity, in such buildings and structures people feel more cheerful, more energetic. Green building technologies in the operation of a building help to reduce payments for resources (electricity, water), as well as contribute to higher rates from a marketing point of view.

In Russia, the "green" education of society so far brings less tangible benefits. The number of buildings that meet the requirements of any voluntary certification system, including the domestic one, is only a few dozen. A study of public opinion shows that about $70 \%$ of the surveyed population of Russia has matured to the understanding that it is necessary to live and work in a healthy building.

At this stage in the development of green building in Russia, it is important to improve and update the regulatory framework that would meet modern trends in the introduction of "green" technologies in the construction and operation of buildings and structures.

It is necessary to actively create and develop national standards for green building. Here, state requirements for mandatory certification of public buildings in accordance with the national environmental standard are possible. Our country has developed its own certification system, which today is of a voluntary nature and was applied mainly to stadiums built before the 2018 FIFA World Cup. At the same time, the Russian certification system was adopted by international organizations (FIFA), which is a good precedent [14].

One of the main tasks set by the media is to educate both builders and consumers, explaining the benefits of green building. Due to the lack of knowledge and information about green building, companies, contractors are conservative in the development of appropriate technologies or methods, they see more problems from green projects than benefits from them. Thus, there is a strong need for demonstration projects to promote and demonstrate any effective green technologies and construction methods [19].

Discussions in the media on the topic of what green architecture and green building are, are very useful, could we consider sufficient the support for this movement from government agencies, the same Ministry of Construction of the Russian Federation, the development of legislation in this area. Pilot projects using green technologies that do not require large investments can become the beginning of the active development and implementation of green technologies in construction in Russia.

Compared to traditional projects, green building projects require more new interdisciplinary knowledge from project participants, more frequent project meetings, which are necessary to facilitate the exchange of knowledge and innovative solutions to problems [20]. Communication and collaboration were identified as key factors in the successful implementation of a green building project. Due to the higher complexity of green building projects, delays can occur due to lengthy certification and permitting processes, and more changes and variations can occur during the construction phase. This perception of risk prevents construction companies from achieving sustainable development principles [20].

Due to various factors mentioned above, green projects are perceived as riskier in terms of project cost, time and quality. For example, a project may fail to receive green certification and / or fail to achieve a high return after investment [21].

Despite the prevailing view in the construction sector in the past that "green building costs are higher than conventional building", a number of studies have shown that green buildings 
can lead to higher rents and asset values [22]. In fact, a large number of residential and commercial buildings in megacities are owned and operated by developers and tenants. For these properties, the rental rate acts as an important economic factor in making decisions in favor of sustainable development. Previous studies have shown that green buildings can attract more targeted and foreign tenants. Meanwhile, given the lower operating costs, commercial tenants in green buildings were found to be more loyal than in conventional ones [9]. Higher economic returns can motivate developers to invest in green building development.

Russian practice cannot really confirm the quantitative data on savings and efficiency obtained in other countries. Compliance with the building "green" standards does not lead to a significant increase in rental rates, capitalization. Reducing operating costs is one of the main economic effects and drivers of green building in Western markets. In Russia, due to the lower cost of resources and, consequently, the volume of their share in operating costs, the financial effect of resource-saving technologies is much lower.

Along with increasing social awareness of sustainable development, more and more construction actors will discover a large market potential of green building. For example, integrating environmental ideas into construction projects helps create free advertising and media coverage for construction companies, which can increase the value of stocks and company ratings [23]. Meanwhile, previous studies have also shown that the experience of green building, creating a green image for a company through investments in green building can help companies to take leading positions in the construction market and lead to an increase in their opportunities for future projects. In addition to market positioning, conventional and green building have been found to have different effects on energy and water consumption, health and safety of the population [7].

Another side of green building in Russia may open up. If the trends towards the development of the market for "green" technologies keep the pace taken today, in a few years we can expect big changes in the field of housing and communal services. Indeed, the certification process makes transparent many previously hidden features of the work of housing and communal services and management details.

The purpose of this study was to examine the obstacles affecting the implementation of green building projects in Russia. To achieve this goal, it was necessary to solve the following tasks: 1) using the analysis of the literature to determine the obstacles (interferences) of various levels, affecting the development of green building; 2) conduct a survey of construction workers and rank the specified obstacles that hinder the implementation of green building projects.

После тщательного изучения литературы, относящейся к препятствиям на пути зеленого строительства, были выявлены и обобщены факторы, которые могут помешать развитию зеленого строительства в России. Для исследования были отобраны факторы, хорошо известные всем заинтересованным сторонам, понятные участникам исследования.

After a thorough study of the literature related to obstacles to green building, the factors that could hinder the development of green building in Russia were identified and summarized. For the study, obstacles were selected that are well known to all stakeholders and understandable to the research participants. They are presented in Table 1. 
Table 1. Possible obstacles to green building.

\begin{tabular}{|c|l|}
\hline № & \multicolumn{1}{|c|}{ Obstacle } \\
\hline 1. & Higher cost of green building compared to conventional \\
\hline 2. & Lack of necessary knowledge and information about green building \\
\hline 3. & Lack of green building demonstration projects \\
\hline 4. & Lack of work experience (qualified personnel) in green building projects \\
\hline 5. & Lack of government incentives / support for green building projects \\
\hline 6. & Lack of education and research in green building \\
\hline 7. & Lack of necessary knowledge about green building assessment systems / schemes \\
\hline 8. & $\begin{array}{l}\text { Lack of necessary experience / skills with green building assessment systems / } \\
\text { schemes }\end{array}$ \\
\hline 9. & Lack of interest and market demand for green building \\
\hline 10. & Lack of clearly defined goals for green building at the initial stage of the project \\
\hline 11. & $\begin{array}{l}\text { A high degree of mistrust in green construction on the part of customers, } \\
\text { contractors, clients }\end{array}$ \\
\hline 12. & $\begin{array}{l}\text { The presence of resistance to the transition to green building on the part of the } \\
\text { subjects of construction activities }\end{array}$ \\
\hline 13. & $\begin{array}{l}\text { Implementation of green building elements is time-consuming and delays in } \\
\text { project implementation }\end{array}$ \\
\hline 14. & Strict and challenging requirements associated with green building projects \\
\hline 15. & $\begin{array}{l}\text { Risks and uncertainties associated with the implementation of green building } \\
\text { projects }\end{array}$ \\
\hline 16. & Difficulties caused by the need for training / advanced training of project personnel \\
\hline 17. & $\begin{array}{l}\text { Lack of communication and cooperation among participants in a green building } \\
\text { project }\end{array}$ \\
\hline 18. & Difficulties in assessing the profitability of green building projects by stakeholders \\
\hline 19. & $\begin{array}{l}\text { Lack of financing and incentives for green building (e.g. bank loans, discounts, } \\
\text { tax deductions) }\end{array}$ \\
\hline
\end{tabular}

\section{Methods}

The questionnaire method was used as a systematic data collection method. The author has developed the questionnaire especially for this study. The questionnaire was sent to 55 participants, and 48 fully completed copies were received and analyzed. All respondents had a higher technical education and experience in the construction industry for at least 3 years, as well as experience in participating in the implementation of green building projects. The survey involved respondents from a variety of subject areas, including urban planning (17\%), project management $(16 \%)$, operation of buildings and structures $(22 \%)$, civil engineers $(20 \%)$.

Prior to the questionnaire, a pilot study was conducted to examine the completeness and validity of the questionnaire. The pilot study involved 4 experts who had experience in this area. The experts were asked to rate the severity of each obstacle (see Table 1) for the implementation of green building projects on a five-point scale (from 1 - not at all manifested to 5 - clearly manifested). Some items of the questionnaire have been changed based on feedback from the pilot study. The reliability of the method was verified, the value of Cronbach's alpha was 0.885 . Consequently, the collected sample can be used for further ranking, t-criterion and analysis of compliance. Respondents were asked to assess the degree of their agreement regarding the severity of obstacles using five-point Likert scale, from 1 to 5: 1 - not at all manifested, 2 - not manifested, 3 - difficult to answer, 4 - manifested, 5 clearly manifested. 


\section{Results}

The survey participants wre asked to rate the importance of each of the 19 obstacles to green building projects. The methodology of ranking by average score was applied to rank and determine priorities among several factors. This is a suitable method for checking the critical level and significance level of factors [24].

The results are presented in Table 2, it displays only 10 obstacles with high ratings, in descending order of importance of the estimates. Student's t-test results (one-sample t-test, $p$ $<0.05$ ) (p - level of significance) [24] indicate that the 10 obstacles presented in Table 2 were significant for the implementation of green building projects (compared to projects conventional construction). The value of the Pearson's criterion Chi-Square was 197.56 with $\mathrm{df}=18, \mathrm{p}<0.01$. It significantly exceeds the critical value 34.805 for $\mathrm{df}=18, \mathrm{p}=0.01$.

Table 2. Rating of obstacles to the implementation of green building projects.

\begin{tabular}{|l|c|c|}
\hline \multicolumn{1}{|c|}{ Obstacles } & $\begin{array}{c}\text { Mean } \\
\text { score }\end{array}$ & SD \\
\hline $\begin{array}{l}\text { 1. Lack of necessary knowledge and information about green } \\
\text { building }\end{array}$ & 4.13 & 0.739 \\
\hline 2. Higher cost of green building compared to conventional & 4.01 & 0.762 \\
\hline 3. Lack of interest and market demand for green building & 3.93 & 0.864 \\
\hline $\begin{array}{l}\text { 4. Risks and uncertainties associated with the } \\
\text { implementation of green building projects }\end{array}$ & 3.78 & 0.763 \\
\hline $\begin{array}{l}\text { 5. The presence of resistance to the transition to green } \\
\text { building on the part of the subjects of construction activities }\end{array}$ & 3.71 & 0.962 \\
\hline $\begin{array}{l}\text { 6. Lack of government incentives / support for green building } \\
\text { projects }\end{array}$ & 3.66 & 0.929 \\
\hline $\begin{array}{l}\text { 7. Lack of work experience (qualified personnel) in green } \\
\text { building projects }\end{array}$ & 3.59 & 0.916 \\
\hline $\begin{array}{l}\text { 8. Lack of financing and incentives for green building (e.g. } \\
\text { bank loans, discounts, tax deductions) }\end{array}$ & 3.47 & 0.974 \\
\hline $\begin{array}{l}\text { 9. Lack of necessary experience / skills with green building } \\
\text { assessment systems / schemes }\end{array}$ & 3.41 & 0.898 \\
\hline $\begin{array}{l}\text { 10. Lack of necessary knowledge about green building } \\
\text { assessment systems / schemes }\end{array}$ & 3.38 & 0.994 \\
\hline
\end{tabular}

The first place, according to the respondents, is "lack of necessary knowledge and information about green building" (average value $=4.13$, SD - standard deviation), which, therefore, is considered the most serious obstacle to the implementation of green building projects.

The second place is taken by "higher cost of green building, compared to conventional". The third place is taken by "Lack of interest and market demand for green building" (average values $=4.01,3.93$, respectively).

The fourth and fifth places are occupied by obstacles: "risks and uncertainties associated with the implementation of green building projects" and "the presence of resistance to the transition to green building on the part of the subjects of construction activities" (average values $=3.78,3.71$ respectively). In sixth place is "lack of government incentives / support for green building projects" (average = 3.66). In seventh place is "lack of work experience (qualified personnel) in green building projects" (average value $=3.59$ ).

It is interesting to note that "lack of financing and incentives for green building" is ranked sixth, and "implementation of green building elements is time-consuming and delays in project implementation" (in 13th place) did not hit the first 10 obstacles. This data contrasts 
with what has previously been reported by other researchers $[16,25]$ that timing and funding are critical obstacles to green building projects.

\section{Discussion}

Green building can be viewed as a complex knowledge structured by design and construction standards. The level of its development directly depends on the achievements of science and technology, on the activity of professional engineers and on the society's awareness of the need to comply with the principles of environmental protection and social responsibility. To help accelerate the introduction of green building, the promotion of projects, this study identifies and analyzes the main obstacles on the way.

As the most important obstacle to the successful and widespread implementation of green building projects in Russia, the respondents indicated "lack of necessary knowledge and information about green building". The high rank of this obstacle is consistent with the results of other studies, which state that the lack of knowledge and understanding of green building by stakeholders, such as contractors, subcontractors, clients and civil engineers, is the main obstacle to the introduction of green building [19]. Currently, the first steps are being taken in Russia to create awareness raising programs that specifically target market opportunities of green building among stakeholders. In practice, non-ecological thinking still prevails. While green building is increasingly gaining the attention of the construction industry in Europe, the United States and other countries, many stakeholders in Russia are unaware of its benefits. The accumulation and exchange of knowledge is critical to advance the sustainable development agenda in the construction industry [26]. Green building should be considered as a mechanism for ensuring sustainable development of the territory where the construction site is located.

As expected, "higher cost of green building compared to conventional" was identified as an important obstacle to green building projects in Russia; it is in the second place. The high criticality of cost in curbing the widespread adoption of green building is confirmed in the scientific literature, while many green buildings in some cases can be built at a comparable or sometimes even lower cost than conventional ones [21]. Green building requires the use and integration of new and innovative green technologies, which usually cost more than their non-sustainable counterparts, so construction actors are hesitant to undertake their implementation. In the construction industry, almost all stakeholders show concern about cost in the first place when considering the possibility of applying new methods and technologies [26]. Lack of knowledge and understanding of the real costs and benefits of green building can be one of the key points to exaggerate cost concerns.

The need to introduce green standards in construction, however, is obvious. Their use allows:

- to reduce the consumption of heat and electricity by at least $50 \%$;

- significantly reduce environmental pollution;

- to reduce water consumption;

- to reduce utility rates;

- to provide a comfortable ecological environment;

- to design modern landscape and architectural solutions.

Construction costs according to green standards will soon pay off due to significant cost savings in building operation, up to $25-30 \%$ [27,28].

In third place is indicated "lack of interest and market demand for green building" [27]. In fourth place are "risks and uncertainties associated with the implementation of green building projects" [28].

These results are associated with a number of features of green building in Russia. 
Interest in green building and certification in Russia is observed mainly on the part of foreign companies, which leads to the low popularity of domestic standards. Russian companies receive green certificates mainly for the marketing and other competitive advantages of their properties. The use of standards for their intended purpose - to optimize resource consumption, increase labor productivity, environmental friendliness, facility safety, is rare. Every 1-2 years, new national standards appear, developed, among other things, by commercial structures. World-class events such as the 2018 FIFA World Cup and the Olympics are making a significant contribution to the development of green building.

The development of green construction in Russia, its entry to the mass level is hindered by a number of risk factors: lack of working market mechanisms, as well as government support measures: tax incentives, favorable loans, discounts, tax deductions, grants and nonfinancial incentives [27,29].

An interesting conclusion is that the respondents do not believe that "the introduction of elements of green construction takes a lot of time, causes delays in the implementation of the project" (rating 13), and do not assess the time factor as very important for the implementation of a green project, which is not consistent with previous studies as stated earlier. Timing could be expected to be one of the most important obstacles because green building projects tend to cause problems that lead to delays [7]. One possible reason for the low estimate of time factor may be due to an integrated design process that gives enough time for feedback and corrections. Time reserves are often scheduled, with sufficient time allocated to implement each stage of the project within the approved schedule, thus reducing the criticality of delay or exceeding the specified time.

The results of the survey show that "the presence of resistance to the transition to green building on the part of the subjects of construction activities" (ranked fifth) was perceived as a serious obstacle. This conclusion is consistent with previous research [30] on the introduction of energy-saving technologies. Resistance from stakeholders can damage the successful implementation of green projects in Russia. People are by nature resistant to change, and this can be especially evident in the construction industry, where responsibility is a serious issue. Due to its size, fragmentation, diversity of work and low investment in research and demonstration projects, the construction industry is characterized by a relatively slow pace of innovation, including green building [29,30]. In addition, project stakeholders who are accustomed to traditional technologies are not ready to quickly change their methods, attitudes and behavior in order to introduce green building.

In sixth place was "lack of government incentives / support for green building projects", respondents assessed support for green construction projects in Russia as insufficient. Lack of government incentives and support is considered a major obstacle to green innovation in other studies [27].

In Russia, measures of state support for financing green projects are implemented through several channels:

1. Through direct government funding, namely through government programs.

2. According to the Decree of the Government of the Russian Federation of December 14, 2010 N 1016 (as amended on June 7, 2017) "On approval of the Rules for the selection of investment projects and principals for the provision of state guarantees of the Russian Federation on loans or bonded loans attracted for the implementation of investment projects".

3. With the help of the Federal State Autonomous Institution "Russian Fund for Technological Development" (Industrial Development Fund), the purpose of which is crediting the development of new high-tech products, technical re-equipment and the creation of competitive industries based on the best available technologies.

4. There is a tax rate on income tax of $0 \%$ to the tax base determined for transactions with bonds of Russian organizations, which are securities of the high-tech (innovative) sector of the economy [31]. 
Another serious obstacle is "lack of work experience (qualified personnel) in green building projects" (seventh place), as a result of the lack of educational and training programs on green building, a small number of participants. Based on these results, it can be stated that the number of stakeholders with experience in the implementation of green construction projects in Russia is limited.

The conclusion is consistent with data from other sources that the lack of technical knowledge and skills is an obstacle to the implementation of green building projects. Knowledge and experience in green building projects can be considered as the most important organizational factor in their implementation. Therefore, more technically competent stakeholders of green project who have necessary competencies and are familiar with green building projects are needed to move them forward in Russia.

\section{Conclusions}

The number of green building projects will only grow in the future. This study examines the main obstacles to the implementation of such projects in Russia. This study contributes to the body of knowledge and identification of issues that are relevant to participants in the construction industry in the Russian Federation. A wide range of obstacles to the implementation of such projects in Russia is identified, the obstacles were identified and investigated using various methods, including a literature review and questionnaire survey, ranking methodology.

This study examined 19 obstacles, highlighted the 10 most important obstacles, to green building projects, with the most important obstacle being a lack of knowledge and information about green building, followed by higher costs of green building and a lack of interest and market demand for green buildings.

The results of this study are expected to provide information valuable for policymaking in the construction industry and for green building projects in the future. The data obtained will contribute to a deeper understanding of the main problems affecting the implementation of green building projects in Russia.

Despite the fact that green projects have a higher cost and take longer than conventional projects, their implementation can provide a number of additional benefits: higher sale and rental prices for green real estate. Long-term benefits for a company that implements green projects: improved positioning of the company in the market through advertising and media coverage of the company's activities.

Based on the results obtained, the following recommendations can be made to improve the effectiveness of green projects:

- Providing financial rewards to project team members for additional efforts and skills invested in the implementation of green building projects, which will help increase labor productivity in the project team.

- Establishing clear goals for green design and construction in the early stages of the project contributes to increased environmental sustainability, promotes increased marketing benefits.

- Simplification of administrative procedures for green building projects will help to increase project efficiency in terms of cost and terms of implementation.

This study has some limitations that require the attention of future researchers. First, although the sample size was sufficient for statistical analysis, it should be understood that, nevertheless, this is a relatively small sample. Further research is required using larger samples to see if the results differ from those reported in this article. Secondly, in future studies, more advanced methods of statistical analysis may be used. Finally, in a future study, it will be possible to compare the opinions of industry professionals from different countries on the implementation of green building projects, to reduce potential costs. 


\section{References}

1. S.V. Kornienko, E.D. Popova, Construction of Unique Buildings and Structures 4(55), 67-93 (2017) https://unistroy.spbstu.ru/userfiles/files/2017/4(55)/5_kornienko_55.pdf

2. A. Singh, M. Syal, S.C. Grady, et al., American Journal of Public Health 100(9), 16651668 (2010) https://ajph.aphapublications.org/doi/10.2105/AJPH.2009.180687

3. UNEP. Towards a green economy: Pathways to sustainable development and poverty eradication. A synthesis for policy makers (2011) http://www.ipu.org/splz-e/rio+20/rptunep.pdf

4. T. Delreux, S. Happaerts, Environmental Policy and Politics in the European Union (Palgrave Macmillan, London, 2016)

5. M. Raiser, I.S. Gill, Golden Growth : Restoring the Lustre of the European Economic Model (World Bank, Washington, DC, 2012) https://openknowledge.worldbank.org/handle/10986/6016

6. United Nations Program on Human Settlements (UN-Habitat, https://www.un.org/ru/ga/habitat

7. A.W. Marker, S. G. Mason, P. Morrow, Performance Improvement Quarterly 26(4), 524 (2014) https://doi.org/10.1002/piq.21160

8. M. Pitt, M. Tucker, M. Riley, J. Longden, Construction innovation 9(2), 201-224 (2009) https://doi.org/10.1108/14714170910950830

9. Y.C. Kog, P.K. Loh, ASCE Journal of Construction Engineering and Management 138(4), 520-528 (2012) https://doi.org/10.1061/(ASCE)CO.1943-7862.0000464

10. I.A. Provotorov, Ya.A. Rogacheva, FES: Finance. Economy, 3, 19-24 (2016) https://www.elibrary.ru/contents.asp?id=34237259\&selid=26004821

11. L.N. Dwaikat, K.N. Ali, Journal of Building Engineering 18, 303-311 (2018) https://doi.org/10.1016/J.JOBE.2018.03.015

12. Z. Hamedani, F. Huber, 7th International Conference on Urban Regeneration and Sustainability (2012) https://doi.org/10.13140/2.1.3177.0568

13. Haute Qualite Environment (HQE). High Environmental Performance, https://www.behqe.com/cerway/benefits

14. S.G. Sheina, S.A. Tikhomirov, E.N. Minenko, International Journal of Applied Engineering $\quad$ Research 10(12), 31389-31402 (2015) https://www.ripublication.com/Volume/ijaerv10n12.htm

15. A. Golabchi, X. Guo, M. Liu et al., Automation in Construction 95, 72-85 (2018) https://doi.org/10.1016/j.autcon.2018.08.003

16. J.I. Ortiz, E. Pellicer, K.R. Molenaar, Journal of Civil Engineering and Management 24 (3), 254-264 (2018) https://doi.org/10.3846/jcem.2018.1643

17. E. Pellicer, V. Yepes, J.C. Teixeira et al., Construction Management (Wiley Blackwell, Oxford, UK, 2014)

18. V. Knotten, O. Lædre, G.K. Hansen, Architectural Engineering and Design Management 13(6), 479-493 (2017) https://doi.org/10.1080/17452007.2017.1345718

19. D.X. Zhao, B.J. He, C. Johnson, B. Mou, Renewable and Sustainable Energy Reviews 51(C), 1594-1609 (2015) https://doi.org/10.1016/j.rser.2015.07.072 
20. J.I. Ortiz, E. Pellicer, K.R. Molenaar, Project Management Journal 50(2), 226-242 (2019) https://doi.org/10.1177/8756972819827389

21. A. Chegut, P. Eichholtz, N. Kok, Journal of Environmental Economics and Management 98, 102248 (2019) https://doi.org/10.1016/j.jeem.2019.07.003

22. G.M. Winch, Managing Construction Projects (John Wiley \& Sons Ltd, Oxford, UK, 2010)

23. B. Ries, M.M. Bilec, N.M. Gokhan, K.L. Needy, Engineering Economist 51(3), 259295 (2006) https://doi.org/10.1080/00137910600865469

24. P. Maravelakis, Journal of Humanities and Applied Social Sciences 1(2), 87-97 (2019) https://www.emerald.com/insight/content/doi/10.1108/JHASS-08-20190038/full/pdf?title=the-use-of-statistics-in-social-sciences.

25. A. Orsi, I. Guillen-Guillamon, E. Pellicer, Sustainability 12(6), 2276 (2020) https://doi.org/10.3390/su12062276

26. S.Yu. Koshkina, O.A. Korchagina, E.S. Voronkova, Questions of modern science and practice. Series: Biology. Ecology. Bionanotechnology 3(47), 150-158 (2013) http://vernadsky.tstu.ru/pdf/2013/03/19.pdf

27. O.E. Astaf'eva, I.Y. Potapova, Review of Management and Marketing 6 (1S), 13-19 (2016) https://www.econjournals.com/index.php/irmm/article/view/1859

28. S. Yun, W. Jung, S.H. Han, H. Park, Journal of Civil Engineering and Management 21(2), 131-143 (2015) https://doi.org/10.3846/13923730.2013.802715

29. R. A. Popov, A. A. Pospelov, Scientific works of KubGTU 8, 167-175 (2016) https://ntk.kubstu.ru/data/mc/0029/1086.pdf

30. D.E. Yeatts, D. Auden, C. Cooksey, C-F. Chen, Energy Research and Social Science 32, 76-85 (2017) https://dx.doi.org/10.1016/j.erss.2017.03.010

31. I.D. Rakov, Actual problems of economics and law 11(2), 67-82 (2017) https://doi.org/10.21202/1993-047X.11.2017.2.67-82 